\title{
ANALISIS HUKUM PENYELESAIAN SENGKETA MURABAHAH DI PENGADILAN AGAMA
}

(Studi Kasus Putusan Pengadilan Agama Mojokerto Nomor 2860/Pdt.G/2013/PA.Mr)

\author{
Afifi Titazahra \& H.M. Naim \\ Email: atitazahra@gmail.com
}

It is mentioned in the laws article 49 No 32006 that one of religious court's duty is to solve murabahah dispute. However, a case related to murabahah dispute number 2860/Pdt.G/2013/PA.Mr. which is submitted to MojokertoReligius Court was rejected by judges. This research attempt to analyse this (1) What is judges consideration in charge of settling murabahah dispute in a verdict number 2860/Pdt.G/2013/Pa.Mr? (2) What factors affecting the judges verdict number 2860/Pdt.G/2013/Pa.Mr? (3) How do the murabahah financing products eligible with religious advice DSN Indonesian Ulamas Council in terms of murabahah financing? This research use case study. The primary data was taken in Mojokerto Religious Court with the case number 2860/ Pdt.G/2013/Pa.Mr while the secondary data based on law books and journals which is related to sharia economy. Data was collected by using interviews and documentation.

This research conclude this (1) The judges decided to not accept the case number 2860/Pdt.G/2013/Pa.Mr because the murabahah agreement which contain dispute settlement should be resolved through the arbitration institution (BASYARNAS). (2) Factors that influence judges verdict was law and rules that regulate arbitration which is consist of laws No 1 21/2008 on Sharia Banking article 55, Laws no 482009 about Judicial Power article 59, article 1338 the Book of Civil Law and article 21 (3) In addition, a case number 2860/pdt.g/2013/pa mr in form of loan capital was not in accordance with MUI teaching number 4/DSN-MUI/IV/2000 that govern murabahah only for purchase of goods.

Keyword : murabahah, dispute settlement, religious court.

\section{PENDAHULUAN}

Pengadilan Agama memiliki kewenangan mutlak untuk menyelesaikan perkara ekonomi syariah. Hal ini didasarkan atas ketentuan Pasal 49 undang-undang Nomor 3 Tahun 2006 yang menyatakan bahwa "Pengadilan Agama bertugas dan berwenang memeriksa, memutus, dan menyelesaikan perkara di tingkat pertama antara orang-orang yang beragama Islam di bidang perkawinan, waris, wasiat, hibah, wakaf, zakat, infak, sedekah dan ekonomi syariah".

Sebelum diundangkannya Undangundang Nomor 3 Tahun 2006 tersebut, belum pernah ada peraturan perundang-undangan yang secara khusus melimpahkan kewenangan kepada pengadilan tertentu untuk memeriksa dan mengadili perkara ekonomi syariah, ${ }^{1}$ sehingga terdapat hak opsi untuk memilih jika terjadi sengketa ekonomi syariah.

Perselisihan atau sengketa ekonomi syariat merupakan ranah sengketa dalam kegiatan bisnis atau perdagangan. Sengketa ekonomi syariah dapat terjadi sebelum maupun pasca perjanjian disepakati. ${ }^{2}$ Terjadinya suatu sengketa ekonomi syariah disebabkan oleh dua pihak baik perorangan maupun badan hukum

\footnotetext{
${ }^{1}$ Achmad Fauzi, Penyelesaian Sengketa Ekonomi Syariah di Pengadilan Agama, Jurnal Mimbar Hukum dan Peradilan, Ed.77 (Jakarta: YPPHIM, 2013), 173-174

2 Amran Suadi, Penyelesaian sengketa Ekonomi Syariah: Penemuan dan Kaidah hukum, (Jakarta: Prenada Media, 2018), 31
} 
yang melakukan akad atau perjanjian dengan prinsip syariah yang salah satu pihak melakukan wanprestasi dan atau melakukan perbuatan melawan hukum sehingga mengakibatkan pihak yang lain merasa dirugikan. $^{3}$

Pada umumnya sengketa yang muncul dikarenakan ada penipuan atau ingkar janji oleh pihak-pihak atau salah satu pihak tidak melakukan apa yang diperjanjikan untuk dilakukan, pihak-pihak atau salah satu pihak sudah melaksanakan apa yang disepakati akan tetapi tidak sama persis sebagaimana diperjanjikan, pihak-pihak atau salah satu pihak melakukan apa yang diperjanjikan tetapi terlambat dan pihak-pihak atau salah satu pihak melakukan sesuatu yang menurut perjanjian tidak boleh dilakukan sehingga tindakantindakan tersebut menyebabkan sengketa. ${ }^{4}$

Di dalam Undang-Undang Nomor 21 Tahun 2008 tentang Perbankan Syariah, menjelaskan bahwa penyelesaian sengketa dilakukan sesuai dengan akad, dengan upayaupaya musyawarah, mediasi perbankan, Badan Arbitrase Syariah Nasional (Basyarnas) atau lembaga arbitrase lain dan atau melalui pengadilan dalam lingkungan Peradilan Umum. Namun, semenjak dikeluarkannya Putusan Mahkamah Konstitusi Nomor 93/PUU-X/2012 tanggal 29 Agustus 2013 pasal tersebut telah mengalami judicial review sehingga penyelesaian sengketa ekonomi syariah secara litigasi menjadi kewenangan absolut Pengadilan Agama.

Sengketa ekonomi syariah yang menjadi kewenangan Pengadilan Agama dapat berupa berbagai macam bentuk akad, salah satu bentuk akad yang sangat banyak dilaksanakan dalam praktek ekonomi syariah adalah akad murabahah. Yang dimaksud dengan akad murabahah adalah akad jual beli atas barang tertentu, dimana penjual menyebutkan dengan

\footnotetext{
${ }^{3}$ Amran Suadi, Ibid, hal 32

${ }^{4}$ Ibid, 33
}

jelas barang yang diperjual belikan, termasuk harga pembelian barang kepada pembeli, kemudian ia mensyaratkan atasnya laba atau keuntungan dalam jumlah tertentu. Definisi lain murabahah adalah jual beli barang pada harga asal dengan tambahan keuntungan yang disepakati. $^{5}$

Dalam akad murabahah, penjual harus memberitahu harga produk yang ia beli dan menentukan suatu tingkat keuntungan sebagai tambahannya. Murabahah dapat dilakukan untuk pembelian secara pemesanan dan biasa disebut sebagai murabahah kepada pemesan pembelian.

Akad murabahah di lembaga keuangan syariah mendominasi keseluruhan pembiayaan di lembaga keuangan syariah. Akad murabahah prosentasenya lebih besar jika dibandingkan akad bagi hasil, seperti mudharabah dan musyakarah. Konon sekitar 60 persen dari produk perbankan syariah di Indonesia adalah murabahah. Sedangkan, sisanya sebanyak 40 persen merupakan produk mudharabah. Murabahah merupakan perjanjian transaksi dengan cara jual beli. ${ }^{6}$ Dominasi terhadap produk keuangan dengan akad murabahah menjadikan sengketa terhadap akad murabahah juga lebih banyak jika dibandingkan dengan akad yang lain.

Berdasarkan pasal 133 Kompilasi Hukum Ekonomi Syariah, penyelesaian sengketa mengenai murabahah dapat diselesaikan melalui sulh dan atau melalui pengadilan, sebagaimana bunyi pasal tersebut sebagai berikut:

"Apabila salah satu pihak konversi murabahah tidak dapat menunaikan kewajibannya, atau apabila terjadi perselisihan di antara pihak-

\footnotetext{
${ }^{5}$ Muhammad, Model-model Akad Pembiayaan di Bank Sharia, (Yogyakarta: UII Pres, 2009). 57

${ }^{6}$ https://indonesiana.tempo.co/read/115875/2017/08/28/gunotos aparie/dominasi-murabahah-di-bank-syariah. diakses tanggal 4 Juli 2018
} 
pihak terkait, maka penyelesaiannya dilakukan melalui sulh dan atau pengadilan."7

Salah satu sengketa murabahah yang terjadi di Jawa Timur adalah sengketa yang diajukan ke Pengadilan Agama Mojokerto dengan nomor perkara 2860/Pdt.G/2013 yang terjadi antara Para Penggugat melawan Para Tergugat. Sengketa ini bermula dari perjanjian yang dituangkan dalam akad murabahah dan akad murabahah bil wakalah yang dilakukan oleh Para Penggugat dengan Tergugat I, untuk modal usaha. Pada mulanya Para Penggugat dapat melunasi cicilan secara teratur, namun dalam perjalanan, usahanya mulai macet dan tidak dapat melunasi cicilan pada Tergugat I. Selanjutnya Tergugat I menjual agunan dari Para Penggugat untuk melunasi hutang Para Penggugat. Sedangkan Para Penggugat merasa agunan yang dijual oleh Tergugat tersebut nilainya melebihi nilai hutang. Hal inilah yang menjadi masalah antara Para Penggugat dengan Tergugat I, sehingga Para Penggugat mengajukan perkara ke Pengadilan Agama Mojokerto.

Di dalam sengketa murabahah tersebut, pada amar putusan tanggal 30 September 2014 majelis hakim memutus tidak diterima karena Pengadilan Agama tidak memiliki kewenangan. Penelitian yang dilakukan oleh penulis untuk mengetahui mengapa perkara tersebut tidak diterima, faktor apa yang menyebabkan perkara tersebut tidak diterima, juga mengetahui kesesuaian akad murabahah dengan fatwa DSN MUI. Hal inilah yang menjadi latar belakang penulis untuk melakukan penelitian berjudul "Analisis Hukum Penyelesaian Sengketa Murabahah Di Pengadilan Agama (Studi Kasus Putusan Pengadilan Agama Mojokerto Nomor 2860/Pdt.G/2013/PA.Mr).”

\section{PEMBAHASAN}

\footnotetext{
7 Kompilasi Hukum Ekonomi Syari'ah, (Jakarta: Mahkamah Agung RI Dirjen Badilag, 2011), 44
}

\section{Sengketa Ekonomi Syariah dan Penyelesaiannya}

Sengketa adalah pertentangan, perselisihan atau percekcokan yang terjadi antara pihak yang satu dengan pihak lainnya yang berkaitan dengan hak yang bernilai, baik berupa uang maupun benda. Achmad Ali berpendapat sengketa atau konflik merupakan setiap situasi dimana dua atau lebih pihak yang memperjuangkan tujuan-tujuan pokok tertentu dari masing-masing pihak, saling memberikan tekanan dan satu sama lain gagal mencapai satu pendapat dan masing masing pihak saling berusaha untuk memperjuangkan secara sadar tujuan-tujuan pokok mereka. ${ }^{8}$ Sedangkan yang dimaksud dengan ekonomi syariah adalah perbuatan atau kegiatan usaha yang dilaksanakan menurut prinsip syariah antara lain meliputi : bank syariah, lembaga keuangan mikro syariah, asuransi syariah, reksadana syariah, obligasi syariah dan surat berhaga berjangka menengah syariah, sekuritas syariah, pembiayaan syariah, pegadaian syariah, dana pensiun lembaga keuangan syariah, dan bisnis syariah. $^{9}$

Proses sengketa, menurut Suyud Magono, terjadi karena tidak adanya titik temu antara pihak-pihak yang bersengketa. Secara potensial, dua pihak yang mempunyai pendirian atau pendapat yang berbeda dapat beranjak ke situasi sengketa. Secara umum, orang tidak akan mengutarakan pendapat yang mengakibatkan konflik terbuka. Hal ini disebabkan oleh kemungkinan timbulnya konsekuensi yang tidak menyenangkan dimana seseorang (pribadi atau sebagai wakil kelompoknya) harus menghadapi situasi rumit yang mengundang ketidaktentuan sehingga dapat memengaruhi kedudukannya. ${ }^{10}$

\footnotetext{
${ }^{8}$ Achmad Ali, Sosiologi Hukum Kajian Empiris Terhadap Pengadilan, (Jakarta: STIH IBLAM, 2004), 64

${ }^{9}$ Sutomo, dkk, Membumikan Hukum Acara Peradilan Agama, (Yokyakarta: UII Press, 2016), h. 3

${ }^{10}$ Suyud Margono, ADR dan Arbitrase Proses Perkembangan dan Aspek Hukum, (Jakarta, Ghalia Indonesia 2000), h. 34
} 
Sengketa ekonomi syariah terjadi karena terdapat dua pihak yang mengadakan akad atau perjanjian dengan didasari prinsip syariah, kemudian salah satu pihak melakukan wanprestasi atau perbuatan melawan hukum sehingga salah satu pihak merasa dirugikan.

Pada dasarnya terdapat banyak hal yang menyebabkan sengketa ekonomi syariah, antara lain:

1. Proses terbentuknya akad disebabkan pada ketidaksepahaman dalam proses bisnis karena terjebak pada orientasi keuntungan, karakter coba-coba, atau karena ketidakmampuan mengenali mitra bisnis yang mungkin tidak memiliki legal cover.

2. Akad atau kontrak sulit dilaksanakan karena:

1) Para pihak kurang cermat atau kurang hati-hati ketika melakukan perundingan pendahuluan.

2) Tidak mempunyai keahlian untuk mengonstruksikan norma-norma akad yang pasti, adil dan efisien.

3) Kurang mampu mencermati resiko yang potensial akan terjadi atau secara sadar membiarkan potensi itu terjadi.

4) Tidak jujur atau tidak amanah.

Berkenaan dengan paradigma tersebut, terdapat beberapa bentuk akad yang dapat menimbulkan sengketa sehingga mesti diwaspadai, bentuk-bentuk akad tersebut sebagai berikut:

1. Salah satu pihak menemukan fakta bahwa syarat-syaratnya suatu akad, baik syarat subjektif maupun syarat objektif yang ternyata tidak terpenuhi sehingga menuntut pembatalan akad;

2. Akad diputus oleh satu pihak tanpa persetujuan pihak lain dan perbedaan menafsirkan isi akad oleh para pihak sehingga menimbulkan sengketa hukum;

3. Karena salah satu pihak tidak emmenuhi prestasi sebagaimana yang telah diperjanjikan;
4. Terjadinya perbuatan melawan hukum (onregmatige daad)

5. Adanya resiko yang tidak diduga pada saat pembuatan akad/ force majeure/overmach ${ }^{11}$

Penyelesaian sengketa ekonomi syariah, secara umum dapat dilaksanakan dengan cara sebagaimana dibawah ini:

1. Perdamaian (Sulhu)

Langkah pertama yang perlu diupayakan ketika hendak menyelesaikan perselisihan, ialah melalui cara damai. Untuk mencapai hakekat perdamaian, prinsip utama yang perlu dikedepankan adalah kesadaran para pihak untuk kembali kepada Allah (Al-Qur'an) dan Rosul-Nya (Al-Sunnah) dalam menyelesaikan segala persoalan.

Upaya damai tersebut biasanya ditempuh melalui musyawarah (syuura) untuk mencapai mufakat di antara para pihak yang berselisih. Dengan musyawarah yang mengedepankan prinsip-prinsip syari'at, diharapkan apa yang menjadi persoalan para pihak dapat diselesaikan. ${ }^{12}$

Syarat-syarat sahnya suatu perjanjian damai dapat diklasifikasikan kepada beberapa hal sebagai berikut:

a. Hal yang menyangkut subjek

Tentang subjek atau orang yang melakukan perdamaian harus orang yang cakap bertindak menurut hukum. Selain dari itu, orang yang melaksanakan perdamaian harus orang yang mempunyai kekuasaan atau mempunyai wewenang untuk melepaskan haknya atau halhal yang dimaksud dalam perdamaian tersebut. Belum tentu setiap orang yang cakap bertindak mempunyai kekuasaan atau wewenang.orang yang cakap bertindak menurut hukum tetapi tidak mempunyai wewenang untuk memiliki seperti: pertama, wali atas harta benda orang yang berada di bawah perwaliannya. Kedua,

\footnotetext{
${ }^{11}$ Amran Suadi, Penyelesaian Sengketa Ekonomi Syariah Teori dan Praktik, (Jakarta: Penerbit Kencana,2017), 8

${ }^{12}$ Burhanuddin, Hukum Bisnis Syari'ah (Yogyakarta: UII Press, 2011), 243-264.
} 
pengampu atas harta benda orang yang berada di bawah pengampuannya. Dan ketiga, nazir (pengawas) wakaf atas hak milik wakaf yang ada di bawah pengawasannya.

b. Hal yang menyangkut objek

Tentang objek dari perdamaian harus memenuhi ketentuan yakni. Pertama, berbentuk harta, baik berwujud maupun yang tidak berwujud seperti hak milik intelektual, yang dapat dinilai atau dihargai, dapat diserahterimakan dan bermanfaat. Kedua, dapat diketahui secara jelas sehingga tidak melahirkan kesamaran dan ketidakjelasan yang pada akhirnya dapat pula melahirkan pertikaian baru terhadap objek yang sama.

c. Persoalan yang boleh didamaikan

Para ahli hukum Islam sepakat bahwa hal-hal yang dapat dan boleh didamaikan hanya dalam bentuk pertikaian harta benda yang dapat dinilai dan sebatas hanya kepada hak-hak manusia yang dapat diganti. Dengan kata lain, persoalan perdamaian itu hanya diperbolehkan dalam bidang muamalah saja, sedangkan halhal yang menyangkut hak Allah tidak dapat didamaikan.

d. Pelaksanaan perdamaian

Pelaksanaan perjanjian damai bisa dilaksanakan dengan dua cara, yakni di luar sidang pengadilan atau melalui sidang pengadilan. Di luar sidang pengadilan, penyelesaian sengketa dapat dilaksanakan oleh mereka sendiri (yang malakukan perdamaian) tanpa melibatkan pihak lain, atau meminta bantuan orang lain untuk menjadi penengah (wasit), itulah yang kemudian disebut sebagai arbitrase atau dalam syari'at Islam disebut sebagai hakam. ${ }^{13}$

Sedangkan pelaksanaan shulhu ini dapat dilakukan dengan beberapa cara, antara lain:

a. Dengan cara ibra (membebaskan debitor dari sebagian kewajibannya)

\footnotetext{
${ }^{13}$ Abdul Manan, Hukum Syariah Dalam Perspektif Kewenangan Peradilan Agama, (Jakarta: Penerbit Kencana, 2016), 428429
}

b. Dengan cara mufadhah (penggantian dengan yang lain) misalnya shulhu hibah yaitu penggugat menghibahkan sebagian barang yang dituntut kepada tergugat, shulhu bay yaitu penggugat menjual barang yang dituntut kepada tergugat, shulhu ijarah yaitu penggugat mempersewakan barang yang dituntut kepada tergugat. Di pihak lain, sebagai pelaksana perdamaian tergugat melepaskan barang sengketa selain dari yang telah dihibahkan oleh penggugat kepadanya, atau membayar sewa. $^{14}$

\section{Arbitrase Syari'ah (Tahkim)}

Dalam perspektif Islam, "arbitrase" dapat dipadankan dengan istilah "tahkim". Tahkim sendiri berasal dari kata "hakkama". Secara etimologi, tahkim berarti menjadikan seseorang sebagai pencegah suatu sengketa. ${ }^{15}$ Secara umum tahkim memiliki pengertian yang sama dengan arbitrase yang dikenal dewasa ini yakni pengangkatan seseorang atau lebih sebagai wasit oleh dua orang yang berselisih atau lebih guna menyelesaikan perselisihan secara damai, orang yang menyelesaikan disebut "hakam". ${ }^{16}$

Lembaga arbitrase sebenarnya telah dikenal sejak zaman pra Islam. Pada saat itu meskipun belum terdapat sistem peradilan Islam yang terorganisasi, setiap ada persengketaan mengenai hak milik, hak waris dan hak-hak lainnya seringkali diselesaikan melalui juru damai yang ditunjuk oleh mereka yang bersengketa. Lembaga ini selanjutnya dikembangkan sebagai alternatif penyelesaian sengketa dengan memodifikasi yang pernah berlaku pada masa pra Islam.

Arbitrase atau tahkim dilakukan untuk menyelesaikan perkara/ perselisihan secara damai dalam hal keperdataan, selain dapat dicapai melalui inisiatif sendiri dari para pihak,

\footnotetext{
${ }^{14}$ Gemala Dewi, LLM, Hukum Perikatan Islam di Indonesia, (Jakarta: Kencana, 2007), 88

${ }^{15}$ Liwis Ma'luf, Al Munjid al Lughoh wa al-A'lam, (Bairut: Daar al Masyriq, $\mathrm{tt}$ ), 146

${ }^{16}$ Abdul Manan, Op Cit, 430
} 
juga dapat dicapai melalui keterlibatan pihak ketiga sebagai wasit (mediator). Upaya ini biasanya akan ditempuh apabila para pihak yang berperkara itu sendiri ternyata tidak mampu mencapai kesepakatan damai.

Hukum Islam melembagakan tahkim sebagai tatanan yang positif karena tahkim (arbitrase) mengandung nilai-nilai positif dan konstruktif sebagai berikut ini:

1. Kedua belah pihak menyadari sepenuhnya perlunya penyelesaian yang terhormat dan bertanggung jawab.

2. Secara sukarela mereka menyerahkan penyelesaian sengketa kepada orang atau lembaga yang disetujui dan dipercaya.

3. Secara sukarela mereka menyerahkan putusan dan arbiter sebagai konsekuensi atas kesepakatan mereka mengangkat arbiter, kesepakatan mengandung janji dan janji harus ditepati (QS. Al-Isra' ayat 24).

4. Mereka menghargai hak orang lain, sekalipun orang lain itu adalah lawannya.

5. Mereka tidak merasa benar sendiri dan mengabaikan kebenaran yang mungkin ada pada orang lain.

6. Mereka memiliki kesadaran hukum dan sekaligus kesadaran bernegara/bermasyarakat sehingga dapat dihindari tindakan main hakim sendiri (eigenrechting).

7. Sesungguhnya pelaksanaan tahkim/ arbitrase itu di dalamnya mengandung makna musyawarah dan perdamaian. ${ }^{17}$

3. Wilayat Al-Qadha (Kekuasaan Kehakiman)

Dengan disahkannya UU No. 3 Th. 2006 tentang perubahan UU No. 7 Th. 1989 tentang Peradilan Agama telah membawa perubahan besar dalam eksistensi lembaga Peradilan Agama saat ini. Salah satu perubahan mendasar adalah penambahan wewenang lembaga Peradilan Agama antara lain di bidang perkawinan, waris, wasiat, hibah, wakaf, zakat, infaq, shadaqah, dan ekonomi syari'ah

\footnotetext{
${ }^{17}$ Abdul Manan, Op Cit, 430-431
}

(pasa149). Dengan adanya kewenangan ini maka perkara yang timbul terkait dengan penyelesaian sengketa syari'ah selain dapat diselesaikan melalui cara damai (sulhu) dan arbitrase syariah (tahkim), juga dapat diselesaikan melalui lembaga peradilan $(\text { qadha })^{18}$

Sistem penyelesaian sengketa ekonomi syariah di Indonesia secara garis besar dapat diselesaikan dengan dua sistem:

a. Penyelesaian sengketa ekonomi syariah secara litigasi

Penyelesaian sengketa melalui jalur litigasi adalah penyelesaian sengketa melalui lembaga pengadilan. Berkaitan dengan hal tersebut, dalam hal memeriksa perkara ekonomi syari'ah khususnya perkara perbankan syari'ah ada beberapa hal penting yang harus dilakukan terlebih dahulu yaitu:

1. Pastikan terlebih dahulu perkara tersebut bukan perkara perjanjian yang mengandung klausul arbitrase. Pentingnya memastikan hal ini dimaksudkan agar jangan sampai Pengadilan Agama yang memeriksa dan mengadili perkara yang ternyata di luar jangkauan kewenangan absolutnya. Karena kewenangan absolut pengadilan agama tidak menjangkau sengketa atau perjanjian yang di dalamnya mengandung klausul arbitrase.

2. Pelajari secara cermat perjanjian (akad) yang mendasari kerjasama antar pihak ${ }^{19}$

b. Penyelesaian sengketa ekonomi syariah melalui jalur non litigasi

Penyelesaian sengketa ekonomi syariah secara non litigasi merupakan alternatif penyelesaian perkara di luar pengadilan dengan harapan kelak sengketa di bidang ekonomi syariah dapat diselesaikan dalam waktu yang singkat dan tidak terlalu lama dengan motto win-win solution sehingga kegiatan bisnis ekonomi syariah dapat berjalan dengan baik

\footnotetext{
${ }^{18}$ Burhanuddin, Op Cit

${ }^{19}$ Amran Suadi, Op Cit, h. 15-16
} 
dan tidak terhalang oleh sebab berlangsungmya proses persidangan. ${ }^{20}$

Penyelesaian sengketa ekonomi syariah secara non litigasi ini dapat dipilih salah satu dari tiga jenis mekanisme yang ada, mekanisme tersebut adalah sebagai berikut ini:

1) Alternatif Penyelesaian Sengketa (APS)

Penyelesaian sengketa dengan APS ini dilakukan melalui enam cara. Pertama, musyawarah, hal ini sesuai dengan ketentuan pasal 55 ayat (2) Undang-Undang Nomor 21 tahun 2008 tentang Perbankan Syariah dan Undang-undang Nomor 30 Tahun 1999 tentang Arbitrase dan Alternatif Penyelesaian Sengketa. Kedua, dengan mediasi dengan mengikutsertakan pihak ketiga yaitu mediator dalam menyelesaikan sengketa. Ketiga, konsultasi, yaitu tindakan yang bersifat personal antara suati pihak (klien) dan pihak lain yang merupakan konsultan. ${ }^{21}$ Keempat, negosiasi, yaitu cara penyelesaian sengketa dengan cara tawar-menawar untuk mencapai suatu kesepakatan. Kelima, konsiliasi yaitu upaya perdamaian dengan bantuan pihak ketiga dengan mengupayakan pertemuan antara pihak yang berselisih. Keenam, penilaian ahli, yaitu pihak bersengketa meminta bantuan kepada ahli untuk mendapatkan nasihat atas sengketa yang terjadi.

2) Arbitrase

Objek perjanjian arbitrase merupakan sengketa yang akan diselesaikan di luar pengadilan melalui lembaga arbitrase atau lembaga alternatif penyelesaian sengketa lainnya. Lembaga arbitrase yang berperan menyelesaikan sengketa eknomi syariah adalah Badan Arbitrase Syariah Nasional (Basyarnas).

Beberapa ketentuan berkenaan dengan perjanjian dan penerapan klausul arbitrase yaitu:

a. Klausul dibuat para pihak sebelum sengketa timbul;

${ }^{20} \mathrm{Ibid}, 62$

${ }^{21}$ Ibid, 69 b. Perjanjian arbitrase tersendiri yang dibuat oleh para pihak setelah sengketa timbul;

c. Terdapat dua bentuk klausul yaitu, pactum de compromitendo dan acta compromise

d. Perjanjian arbitrase harus dibuat secara tertulis;

e. Perjanjian abitrase bukan perjanjian bersyarat, karenanya tidak dapat digantungkan kepada suatu kejadian di masa yang akan dating;

f. Sifat perjanjian arbitrase merupakan perjanjian accessoir dari perjanjian pokoknya. Ini berarti perjanjian pokok menjadi dasar lahirnya klausul atau perjanjian arbitrase. ${ }^{22}$

3) Penyelesaian Sengketa Ekonomi Syariah Melalui Lembaga Konsumen

Penyelesaian sengketa ekonomi syariah melalui lembaga konsumen diatur dalam Undang-Undang Nomor 8 tahun 1999 tentang Perlindungan Konsumen. Berdasarkan pasal 45 ayat (2) penyelesaian sengketa konsumen dilakukan oleh Yayasam Lembaga Konsumen Indonesia (YLKI) yang berperan sebagai mediator. ${ }^{23}$

\section{Murabahah}

Jual beli murabahah adalah pembelian oleh satu pihak untuk kemudian dijual kepada pihak lain yang telah mengajukan permohonan pembelian terhadap satu barang dengan keuntungan atau tambahan harga yang transparan. $^{24}$ Dapat juga dikatakan murabahah adalah akad jual beli barang dengan menyatakan harga perolehan dan keuntungan (margin) yang disepakati oleh penjual dan pembeli. ${ }^{25}$ Pembayaran atas akad jual beli dapat dilakukan secara tunai maupun kredit. Hal yang membedakan murabahah dengan jual beli lainnya adalah penjual harus memberitahukan

\footnotetext{
${ }^{22}$ Ibid, $85-86$

${ }^{23} \mathrm{Ibid}, 90$

${ }^{24}$ Gemala Dewi, LLM, Hukum Perikatan Islam di Indonesia, (Jakarta: Kencana, 2007), 108

${ }^{25}$ Hasbi Ramli, Teori Dasar Akuntansi Syariah, (Jakarta: Renaisan, 2005), 51
} 
kepada pembeli harga barang pokok yang dijualnya serta jumlah keuntungan yang diperoleh. $^{26}$

Karakteristik murabahah adalah sebagai berikut ini:

1. Harga yang disepakati adalah harga jual, sedangkan harga beli harus diberitahukan.

2. Potongan dari pemasok merupakan hak pembeli, kemudian setelah akad dibagi sesuai perjanjian.

3. Sistem akad murabahah adalah, dalam cara pembayarannya boleh secara tunai atau secara tangguh, menurut jenisnya bisa berdasarkan pesanan atau tanpa pesanan. Murabahah berdasarkan pesanan dapat bersifat mengikat atau tidak mengikat.

4. Transaksi murabahah terdiri dari:

a. Murabahah tanpa pesanan, yaitu bank bertindak sebagai penjual barang yang diperolehnya tanpamendapatkan pesanan lebih dahulu dari nasabah.

b. Murabahah berdasarkan pesanan yaitu bank melakukan pembelian barang setelah ada pemesanan dari nasabah.

5. Murabahah berdasarkan pesanan:

a. Dapat bersifat mengikat: (1) pembeli tidak dapat membatalkan pesanannya (2) aset yang dibeli mengalami penurunan sebelum diserahkan kerugian bank (mengurangi nilai akad).

b. Dapat bersifat tidak mengikat.

6. Pembayaran dalam murabahah dapat dilakukan secara tunai atau dengan cicilan.

7. Bank dapat memberikan potongan apabila nasabah mempercepat pembayaran cicilan atau melunasi piutang murabahah sebelum jatuh tempo.

8. Bank dapat meminta nasabah menyesiakan agunan antara lain barang yang dibeli.

9. Bank dapat meminta urbun sebagai uang muka:

a. Akad jadi dilaksanakan menjadi bagian pelunasan piutang

${ }^{26} \mathrm{Ibid}$ b. Akad batal dikembalikan ke nasabah: (1) setelah dikurangi kerugian bank (2) uang muka lebih kecil kerugian, bank dapat minta tambahan ke nasabah.

10. Denda dalam murabahah:

a. Nasabah mampu tapi tidak mau.

b. Kedisiplinan nasabah terhadap kewajibannya.

c. Besarnya sesuai perjanjian dan diperuntukkan sebagai dana sosial. ${ }^{27}$

\section{Rukun dan Syarat Murabahah}

Rukun adalah suatu elemen yang tidak dapat dipisahkan dari suatu kegiatan atau lembaga, sehingga bila tidak ada salah satu elemen tersebut maka kegiatan terdebut dinyatakan tidak sah atau lembaga tersebut tidak eksis. Menurut Jumhur Ulama ada 4 rukun dalam murabahah, yaitu Orang yang menjual (ba'i'), orang yang membeli (musytari), sighat dan barang atau sesuatu yang diakadkan.

Sedangkan syarat murabahah meliputi: pihak yang berakad, yaitu ba'i' dan musytari harus cakap hukum atau balik (dewasa), dan mereka saling meridhai (rela). Khusus untuk mabi' persyaratanya adalah harus jelas dari segi sifat jumlah, jenis yang akan ditransaksikan dan juga tidak termasuk dalam kategori barang haram. Harga dan keuntungan harus disebutkan begitu pula sistem pembayarannya, semuanya ini dinyatakan didepan sebelum akad resmi (ijab qabul) dinyatakan tertulis. ${ }^{28}$

Syarat yang juga harus dipenuhi dalam transaksi murabahah, menurut Gemala Dewi dkk adalah sebagai berikut:

(1) Jual beli murabahah harus dilakukan atas barang yang telah dimiliki (hak kepemilkan telah berada di tangan penjual). Artinya, keuntungan dan resiko barang tersebut ada pada penjual sebagai konsekuensi dari kepemilikan yang timbul dari akad yang sah. Ketentuan ini sesuai dengan kaidah,

\footnotetext{
27 Ibid, 51-53

28 Ah.Azharudin Latifh, ,Fiqih Muamalat, 119-120
} 
bahwa keuntungan itu terkait dengan resiko dapat mengambil kentungan.

(2) Adanya kejelasan informasi mengenai besarnya modal dan biaya-biaya lain yang lazim dikeluarkan dalam jual beli pada suatu komoditi, semuanya harus diketahui oleh pembeli saat transaksi.

(3) Adanya informasi yang jelas tentang keuntungan, baik nominal maupun persentase sehingga diketahui oleh pembeli sebagai salah satu syarat sah murabahah.

(4) Penjual boleh menetapkan syarat pada pembeli untuk menjamin kerusakan yang tidak tampak pada barang, tetapi lebih baik syarat seperti itu tidak ditetapkan, karena pengawasan barang merupakan kewajiban penjual disamping untuk menjaga kepercayaan yang sebaik-baiknya. ${ }^{29}$

\section{HASIL PENELITIAN}

\begin{tabular}{lrr}
\multicolumn{1}{c}{ Perkara $\quad$ sengketa } & murabahah \\
sebagaimana yang diajukan & oleh para \\
Penggugat & dengan & nomor \\
2860/Pdt.G/2013/Pa.Mr, & sebenarnya
\end{tabular}

merupakan salah satu kegiatan usaha yang dilaksanakan menurut prinsip syariah, yaitu termasuk dalam akad yang dilaksanakan oleh bank syariah. Sehingga pada dasarnya penyelesaian sengketanya merupakan kewenangan Pengadilan Agama.

Penyelesaian sengketa di luar Peradilan Agama tidak dibenarkan karena tidak memenuhi syarat formal dan official serta bertentangan dengan prinsip under the authority of law. Namun berdasarkan Undangundang No 30 Tahun 1999 tentang Arbitrase dan Alternatif Penyelesaian sengketa, klausul Arbitrase Syariah menggugurkan kewenangan lembaga lain untuk menyelesaikan sengketa di antara para pihak, hal ini terdapat dalam ketentuan Pasal 11 UU Arbitrase dan APS yang berbunyi:

\footnotetext{
${ }^{29}$ Gemala Dewi, dkk, Op Cit, 109
}

(1) Adanya suatu perjanjian arbitrase tertulis meniadakan hak para pihak untuk mengajukan penyelesaian sengketa atau beda pendapat yang termuat dalam perjanjiannya ke Pengadilan Negeri.

(2) Pengadilan Negeri wajib menolak dan tidak akan campur tangan di dalam suatu penyelesaian sengketa yang telah ditetapkan melalui arbitrase, kecuali dalam hal tertentu yang ditetapkan dalam Undang-undang. ${ }^{30}$

Di dalam Undang-Undang Nomor 21 Tahun 2008 tentang Perbankan Syariah, dalam penjelasan pasal 55 menjelaskan bahwa penyelesaian sengketa dilakukan sesuai dengan akad, dengan upaya-upaya musyawarah, mediasi perbankan, Badan Arbitrase Syariah Nasional (Basyarnas) atau lembaga arbitrase lain dan atau melalui pengadilan dalam lingkungan Peradilan Umum.

Beberapa faktor yang mempengaruhi pertimbangan hakim dalam memutus perkara sengketa murabahah menurut penulis adalah sebagai berikut ini:

1. Undang-Undang No. 21 Tahun 2008 tentang Perbankan Syariah Pasal 55 menyatakan bahwa:

(1) Penyelesaian sengketa Perbankan Syariah dilakukan oleh pengadilan dalam lingkungan Peradilan Agama.

(2) Dalam hal para pihak telah memperjanjikan penyelesaian sengketa selain sebagaimana dimaksud pada ayat (1), penyelesaian sengketa sesuai dengan isi akad.

(3) Penyelesaian sengketa sebagaimana dimaksud pada ayat (2) tidak boleh bertentangan dengan Prinsip Syariah.

\footnotetext{
${ }^{30}$ Undang-undang Nomor 30 Tahun 1999 tentang Arbitrase dan Alternatif Penyelesaian Sengketa
} 
2. Undang-Undang Nomor 48 tahun 2009 tentang Kekuasaan Kehakiman Pasal 59 yang berbunyi:

1. Arbitrase merupakan cara penyelesaian suatu sengketa perdata di luar pengadilan yang didasarkan pada perjanjian arbitrase yang dibuat secara tertulis oleh para pihak yang bersengketa.

2. Putusan arbitrase bersifat final dan mempunyai kekuatan hukum tetap dan mengikat para pihak.

3. Dalam hal para pihak tidak melaksanakan putusan arbitrase secara sukarela, putusan dilaksanakan berdasarkan perintah ketua pengadilan negeri atas permohonan salah satu pihak yang bersengketa.

Penjelasan Pasal 59 Ayat (1)

Undang-Undang Nomor 48 tahun 2009

tentang Kekuasaan Kehakiman. Yang dimaksud dengan "arbitrase" dalam ketentuan ini termasuk juga arbitrase syariah.

3. Azas "Pacta Sunt Servanda" sebagaimana dimaksud Pasal 1338 KUH Perdata yang menyatakan "Semua perjanjian yang dibuat secara sah, berlaku sebagai undang-undang bagi mereka yang membuatnya", dan Pasal 21 Huruf (b) PERMA No. 2 Tahun 2008 Tentang Kompilasi Hukum Ekonomi Syariah yang menyatakan bahwa "setiap akad wajib dilaksanakan oleh para pihak sesuai dengan kesepakatan yang telah ditetapkan", maka Majelis Hakim berpendapat bahwa eksepsi dari Tergugat I tentang kompetensi absolut (absolute competency).

Selanjutnya Untuk mengetahui kesesuaian produk pembiayaan murabahah yang termuat dalam putusan perkara Pengadilan Agama Mojokerto nomor 2860/Pdt.G/2013/PA.Mr dari posita penggugat hingga amar putusan dikaitkan dengan fatwa MUI No 4/DSN-MUI/IV/2000 tentang Murabahah akan penulis uraikan sebagai berikut:

Dalam ketentuan umum murabahah dipersyaratkan bank dan nasabah harus melakukan akad murabahah yang bebas riba. Yang dimaksud dengan akad murabahah yaitu pembelian oleh satu pihak untuk kemudian dijual kepada pihak lain yang telah mengajukan permohonan pembelian terhadap satu barang dengan keuntungan atau tambahan harga yang transparan. ${ }^{31}$ Dapat juga dikatakan murabahah adalah akad jual beli barang dengan menyatakan harga perolehan dan keuntungan (margin) yang disepakati oleh penjual dan pembeli. ${ }^{32}$ Jadi pelaksanaan akad murabahah yang dimaksud adalah bank membeli barang yang diperlukan oleh nasabah atas nama bank, dan menyampaikan kepada nasabah tentang harga pokok beserta biaya yang diperlukan. Namun dalam gugatannya, para penggugat menyampaikan bahwa akad murabahah yang dibuat antara Para Penggugat dengan Tergugat I adalah berupa modal untuk pertokoan senilai Rp 175.000.000,- (seratus tujuh puluh lima juta rupiah).

Pelaksanaan akad murabahah seharusnya berupa barang yang dibeli oleh pihak bank atas pesanan dari nasabah, namun dalam akad murabahah pada perkara nomor 2860/Pdt/G/2013/PA.Mr. pinjaman tersebut berupa uang untuk modal pertokoan. Menurut penulis, hal ini sudah menyimpang dari ketentuan fiqih yang dituangkan dalam fatwa DSN MUI 4/DSN-MUI/IV/2000.

\section{KESIMPULAN}

Berdasarkan pembahasan yang telah dijabarkan diatas, maka penulis mengambil kesimpulan sebagai berikut:

1. Pertimbangan Majelis Hakim memutus tidak diterima pada perkara nomor 2860/Pdt.G/2013/PA.Mr., karena akad perjanjian murabahah memuat penyelesaian sengketa melalui lembaga arbitrase (BASYARNAS).

\footnotetext{
${ }^{31}$ Gemala Dewi, LLM, Hukum Perikatan Islam di Indonesia, (Jakarta: Kencana, 2007), 108

${ }^{32}$ Hasbi Ramli, Teori Dasar Akuntansi Syariah, (Jakarta: Renaisan, 2005), 51
} 
2. Beberapa faktor yang mempengaruhi putusan majelis hakim adalah peraturan perundang-undangan yang mengatur masalah arbitrase yaitu Undang-Undang No. 21 Tahun 2008 tentang Perbankan Syariah Pasal 55, Undang-Undang Nomor 48 tahun 2009 tentang Kekuasaan Kehakiman Pasal 59, dan aturan yang menyangkut akad yaitu Pasal 1338 KUH Perdata dan Pasal 21 Huruf (b) PERMA No. 2 Tahun 2008 Tentang Kompilasi Hukum Ekonomi Syariah.

3. Terdapat ketidaksesuaian akad pembiayaan murabahah pada perkara nomor 2860/Pdt.G/2013/PA.Mr. dengan fatwa DSN MUI Nomor 4/DSN-MUI/IV/2000. Dimana seharusnya akad murabahah berupa pembelian barang, namun dalam perjanjian akad murabahah pada perkara nomor 2860/Pdt.G/2013/PA.Mr., pinjaman berupa modal usaha.

\section{SARAN}

Adapun saran yang dapat peneliti kemukakan berdasarkan temuan dalam penelitian ini adalah:

1. Kepada para peneliti, untuk melanjutkan penelitian mengenai penyelesaian sengketa murabahah yang dilakukan melalui cara non litigasi, baik melalui Basyarnas maupun lembaga konsumen.

2. Kepada nasabah dalam pembuatan akad diharapkan lebih mencermati isi akad agar tidak salah ketika hendak menyelesaikan sengketa, sehingga tidak rugi waktu, tenaga, maupun biaya.

3. Untuk pembuatan akad-akad di Lembaga Keuangan Syariah, hendaknya dalam klausul penyelesaian sengketanya, memilih penyelesaian sengketa melalui Pengadilan Agama. 


\section{DAFTAR PUSTAKA}

Ali, Achmad, Sosiologi Hukum Kajian Empiris Terhadap Pengadilan, Jakarta: STIH IBLAM, 2004

Burhanuddin, Hukum Bisnis Syari'ah. Yogyakarta: UII Press, 2011

Dewi. Gemala, LLM, Hukum Perikatan Islam di Indonesia, Jakarta: Kencana, 2007

Fauzi, Achmad, Penyelesaian Sengketa Ekonomi Syariah di Pengadilan Agama, Jurnal Mimbar Hukum dan Peradilan, Ed.77. Jakarta: YPPHIM, 2013

Latifh, Ah.Azharudin Latif, Fiqih Muamalat, Jakarta: UIN Jakarta, 2005.

Suadi, Amran, Penyelesaian sengketa Ekonomi Syariah: Penemuan dan Kaidah hukum, Jakarta: Prenada Media, 2018

Suadi, Amran, Penyelesaian Sengketa Ekonomi Syariah Teori dan Praktik, Jakarta: Penerbit Kencana, 2017

Sutomo, dkk, Membumikan Hukum Acara Peradilan Agama, Yokyakarta: UII Press, 2016

Muhammad, Model-model Akad Pembiayaan di Bank Sharia, Yogyakarta: UII Pres, 2009

Margono, Suyud, ADR dan Arbitrase Proses Perkembangan dan Aspek Hukum, Jakarta, Ghalia Indonesia 2000

Ma'luf, Liwis, Al Munjid al Lughoh wa alA'lam, Bairut: Daar al Masyriq, tt

Ramli, Hasbi, Teori Dasar Akuntansi Syariah, Jakarta: Renaisan, 2005

Undang-undang Nomor 30 Tahun 1999 tentang Arbitrase dan Alternatif Penyelesaian Sengketa

PERMA No. 2 Tahun 2008 Tentang Kompilasi Hukum Ekonomi Syariah https://indonesiana.tempo.co/read/115875/2017 /08/28/gunotosaparie/dominasimurabahah-di-bank-syariah 